\title{
RECENT BRYOLOGICAL LITERATURE OF THE FORMER USSR. II
} НОВАЯ БРИОЛОГИЧЕСКАЯ ЛИТЕРАТУРА ПО БЫВШЕМУ СССР. II

\author{
IRINA V. CZERNYADJEVA ${ }^{1} \&$ Michael S. IGNATOV ${ }^{2}$ \\ ИРИНА В. ЧЕРНЯДЬЕВА ${ }^{1}$ и МИХАИЛ С. ИГНАТОВ ${ }^{2}$
}

We are prolonging to publish recent bibliography of bryological literature, which either were published on the territory of the former USSR or deal with floristic and taxonomic investigations on its territory. In the present paper there cited publications which appeared mostly in 1993-1995 (short theses of conferences are usually omitted).

ABOLINA, A. 1994. Latvijas retas un aizsargajamas sunas. - [Rare and protected mosses in Latvia] Vides Aizsardziba Latvija (Riga) 6: 3-24.

[ABRAMOVA, A. L. \& Ts. TSEGMED] АБРАMOBA, А. Л., Ц. ЦЭГМЭД 1993. Новые и редкие виды мхов Монголии. - [The new and rare species of mosses from Mongolia] Новости сист. низи. pacm. [Novosti Sist. Nizsh. Rast.] 29: 128-132.

[ABRAMOVA, A. L. \& Ts. TSEGMED] АБРАMOBA, А. Л., Ц. ЦЭГМЭД 1994. Новые роды и виды мхов во флоpe Монголии. - [The new genera and species of mosses in the Mongolian flora] Бот. Журн. [Bot. Zhurn.] 79(10): 138-143.

[AFONINA, O. М.] АФОНИНА, О. М. 1994. Заметки о мхах Чукотки 1. Виды рода Pohlia (Bryaceae) с выводковыми почками. - [Notes on mosses of Chukotka. 1. Propaguliferous species of the genus Pohlia (Bryaceae)] Бот. Журн. [Bot. Zhurn.] 79(2): 102-105.

[AFONINA, O. М.] АФОНИНА, О. М. 1994. Флора окрестностей бухты Сомнительной: мохообразные. - [Flora of the vicinities of Somnitelnaya Bay: bryophytes.] $B$ кн: Арктические тундры острова Врангеля (Материалы ботанического полустачионара "Бухта Сомнительная” 1984-1988 г2.) (ред. Б. А. Юриев). СПб., РАН, Бот. Ин-т им. В. Л. Комарова. [In: В. А. Yurtsev (ed.) Arcticheskie tundry ostrova Vrangelya (Materialy botanicheskogo polustatsionara "Bukhta Somnitelnaya”, 1984-1988) St-Petersburg, Bot. Inst. Russ. Acad. Sci.]: 66-90.

AFONINA, O. М. [АФОНИНА ,О. М.] 1995. Памяти Ивана Ивановича Абрамова (1912-1990). - [Ivan Ivanovich Abramov (1912-1990)] Arctoa 4: 105-117.

AFONINA, O. М. [АФОНИНА ,О. М.] 1995. Интересные находки листостебельных мхов на Чукотке. - [ Interesting findings of mosses in Chukotka] Новости сист. низи. pacm. [Novosti Sist. Nizch. Rast.] 30: 93-97.
Мы продолжаем публикацию библиографии новых бриологических работ, которые либо были опубликованы на территории бывшего СССР, либо посвящены флористическим и таксономическим исследованиям этих территорий. В данный выпуск включены работы, вышедшие в основном в 1993-1995 гг. (тезисы конференций не приводятся).

AFONINA, O. М. [АФОНИНА, О. М.] 1995. Эксикаты мохообразных России и сопредельных государств. - [Bryophyta Rossica et civitatum collimitanearum] СПб., БИН РАН [St-Petersburg, Bot. Inst. Russ. Acad. Sci.] 1(№ 1-25): 1-19; 2(№ 26-50): 1-10; 3(№ 51-75): 1-10; 4(№ 76-100): 1-10.

[AFONINA, O. M. \& E. N. ANDREEVA] АФОНИНА, О. М., Е. Н. АНДРЕЕВА 1993. О нахождении спорогонов мxa Lyellia aspera (Hag. et C. Jens.) Frye. - [About finding of the sporophytes of Lyellia aspera (Hag. et C. Jens.) Frye] Новости сист. низи. pacm. [Novosti Sist. Nizch. Rast.] 29: 132-138.

AFONINA, O. M. \& I. V. CZERNYADJEVA 1995. Mosses of the Russian Arctic: check-list and bibliography. Arctoa 5: 99-142.

[AFONINA, O. М. \& J. DUDA] АФОНИНА, О. М., Й. ДУДА 1993. Печеночные мхи Чукотки. - [Liverworts of Chukotka] Бот. Журн. [Bot. Zhurn.] 78(3): 77-93.

[AFONINA, O. M. \& R. OCHYRA] АФОНИНА, O. М., P. ОХЫРA 1994. Schistidium cryptocarpum (Musci, Grimmiaceae) - новый вид для Евразии. - [Schistidium cryptocarpum (Musci, Grimmiaceae) - a species new to Eurasia] Бот. Журн. [Bot. Zhurn.] 79(10): 128-133.

[AFONINA, O. M. \& N. A. SEKRETAREVA] АФОНИНА, О. М., Н. А. СЕКРЕТАРЕВА 1994. Мхи ивовых кустарниковых и тундровых сообеств верхнего течения реки Неизвестной (остров Врангеля). - [The mosses of the willow shrub communities and tundra communities in the Upper Reaches of the Neizvestnaya River, Wrangel Island] Бот. Журн. [Bot. Zhurn.] 79(7): 43-52.

[ANANIAN, V. L., L. A. ARARATIAN \& V. A. MANAKYAN] АНАНЯН, В. Л., Л. А. АРАРАТЯН, В. А. МАНАКЯН 1991. Накопление химических элементов и радионуклидов мхами. - [Accumulation of chemical ele-

1 - Botanical Institute of Russian Academy of Sciences, Popova, 2, St.-Petersburg 197376 Russia - Россия 197376 Санкт-Петербург, проф. Попова, 2, Ботанический институт РАН

2 - Main Botanical Garden of Russian Academy of Sciences, Botanicheskaya, 4, Moscow 127276 Russia - Россия 127276 Москва, Ботаническая, 4, ГБС РАН 
ments and radionuclids in mosses] Экология [Ecologia] (1991) N 2: 82-85.

[ANDREEV, M. P., O. M. AFONINA \& A. D. POTEMKIN] АНДРЕЕВ, М. П., О. М. АФОНИНА, А. Д. ПОТЕМКИН 1993. Мохообразные и лишайники островов Комсомолец и Большевик (Архипелаг Северная Земля ). - [Bryophytes and lichens of the Komsomolets and Bolshevik Islands (The Severnaya Zemlya Archipelago)] Бот. Журн. [Bot. Zhurn.] 78(2): 69-79

[BABENKO, L. А.] БАБЕНКО, Л. А. 1995. Флора мохообразных Ростовской области. - [The bryoflora of Rostov Province] Трудь V молодежной конф. ботаников в Санкт-Петербурге (ред. Росков, Ю. Р., С. И. Чубаров), СПб, БИН РАН [In: Roskov, Yu. R. \& S. I. Chubarov (eds.) Trudy V molodezhnoj konf. botanikov v Sankt-Petersburge. St.-Petersburg, Bot. Inst. Ross. Akad. Nauk]: 48-51.

[BABENKO, L. A. \& V.A. BOLYUKН] БАБЕНКО, Л.А., В. А. БОЛЮХ 1996. Рідкісні мохоподібні еколого-ценотичнчх комплексів Нижнього Дону та центральноі частини Поділля. - [Rare bryophytes of the ecology-coenotic complexes of Lower Don River and Central Podolia] $У_{\kappa p}$. Бот. Журн. [Ukr. Bot. Zhurn.] 53(1/2): 141-143.

[ВАІК, О. L.] БАІК, О. Л. 1993. Внутрішньовидова мінливість листяних мохів, iі природа та адаптивне значення. - [Intraspecific variability of mosses, its nature and adaptive significance] Автореф.... канд. биол. наук, Киів, Iнст. Бот. АНУ [Ph. D. Thesis, Kiev, Inst. Bot. Akad. Nauk. Ukr.], 23.

[BAIK, O. L., I. S. DANILKIV \& R. T. RIPETSKY] БAIK, О. Л., І. С. ДАНИЛКІВ, Р. Т. РІПЕЦЬКИЙ 1994. ВПлИв свинцю на кислі розчинні білки, естеразу і пероксидазу хромосомних рас Tortula subulata Hedw. - [The effect of a lead on sour soluble proteins, esterase and peroxidase of chromosome races of Tortula subulata Hedw.] $У_{\kappa p}$. Бот. Журн. [Ukr. Bot. Zhurn.] 51(1): 61-66.

BAISHEVA, E. Z. 1995. Bryophyte vegetation of Bashkiria, South Urals. II. Epiphytic and epixylic communities of north-eastern Bashkiria. - Arctoa 4: 55-63.

[BAISHEVA, E. Z.] БАИШЕВА, Э. 3. 1995. Синтаксономия эпифитной и эпиксильной моховой растительности в лесах Башкирии. - [The syntaxonomy of the bryophytic epiphytic and epixylic vegetation in the forests of Bashkiria] Автореф... канд. биол. наук, Уфа, Ин-т Биол. УНЦ РАН [Thesis Ph. D., Ufa, Inst. Biol. Uralsk. Nauchn. Centr. Ross. Akad. Nauk, ], 15.

[BAISHEVA, E. Z. \& A. I. SOLOMETCH] БАИШЕВA, Э. З., А. И. СОЛОМЕЩ 1994. Бриосинтаксономия: эпифитные и эпиксильные сообщества. - [The syntaxonomy of the bryophytic epiphytic and epixylic communities] Бюлл. МОИП, Отд. Биол. [Byull. Mosk. Obsch. Isp. Prir., Otd. Biol.] 99(6): 74-85.

[BAISHEVA, E. Z., A. I. SOLOMETCH \& E. A. IGNATOVA] БАИШЕВА, Э. З., А. И. СОЛОМЕЩ, Е. А. ИГНАТОВА 1993 Синтаксономия эпифитной и эпиксильной моховой растительности Башкирии. - [The syntaxonomy of the epi phytic bryophytic vegetation of Bashkiria] Уфа, Ин-т биол. УНЦ РАН, 1993. Деп. ВИНИТИ 18. 11. 1993, N 2854-B93 [Ufa, Inst. Biol. Uralsk. Nauchn. Centr. Ross. Akad. Nauk, 1993. Msc. Re served in VINITI, 18. 11. 1993, N 2854-B93], 49.
BAISHEVA, E. Z. \& A. I. SOLOMETCH \& E. A. IGNATOVA. 1994. Bryophyte vegetation of Bashkiria, South Urals. I. Epiphytic and epixylic communities. - Arctoa 3: 139-151.

[BARDUNOV, L. V. \& V. Ya. CZERDANTSEVA] БAPДУНОВ, Л. В., В. Я. ЧЕРДАНЦЕВА. 1994. Редкие и интересные виды южнодальневосточной флоры мхов в заповедниках юга Российского Дальнего Востока. - [Rare and interesting mosses of South Far East of bryoflora from state nation reserve of southern part of Russian Far East] Материаль совещания "Природоохранные территории и акватории Дальнего Востока и проблемы сохранения биологического разнообразия” (ред. Абрамов, В. К. и др.). Владивосток, Биол.-Почв. ин-т ДВО РАН [In: Abramov, V. K. \& al. (eds.) Materialy soveshchaniya "Prirodoochrannye territorii i akvatorii Dal'nego Vostoka i problemy sochraneniya biologicheskogo rasnoobraziya". Vladivostok, Biol.-Pochv. Inst. Dalnevost. Otd. Ross. Akad. Nauk]: 73-77.

[BELKINA, O. A. \& N. A. KOnSTANTINOVA \& V. A. KOSTINA] БЕЛКИНА, О. А., Н. А. КОНСТАНТИНОВА, В. А. КОСТИНА 1991. Флора высших растений Ловозерских гор. [The flora of higher plants of Lovozerskiye Mountains] СПб., Наука. [St.-Petersburg, Nauka], 206.

[BELKINA, O. A., N. A. KONSTANTINOVA \& A. Yu. LIKHACHEV \& R. N. SCHLJAKOV] БЕЛКИНА, О. А., Н. А. КОНСТАНТИНОВА. А. Ю. ЛИХАЧЕВ, Р. Н. ШЛЯKOB 1990. Мохообразные. - [Bryophytes] В кн. : Редкие и нуждаюшиеся в охране растения и животные Мурманской области. Мурманск, Мурманское книжное изд-во. [Redkie $i$ nuzhdayushchiesya v ohrane rasteniya i zhivotnye Murmanskoj oblasti. Murmansk, Murmanskoe knizhnoe izd-vo]: 84-89.

[BLAGODATSKIKH, L. S.] БЛАГОДАТСКИХ, Л. С. 1995. Материалы к флоре мохообразных Оренбуржья. [On moss flora of Orenburg Province] Bonpoca cmenной биоченологии (ред. Мухин, В. А. ), Екатеринбург, УрО PAH [In: Mukhin, V. A. (ed.) Voprosy stepnoj biotsenologii. Ekaterinburg, Russ. Akad. Nauk., Ural'skoe Otd.]: 17-21.

[BLAGOVESHCHENSKY, V. V., A. V. MASLENNIKOV, A. N. MORDVINOV, N. S. RAKOV \& M. V. SHUSTOV] БЛАГОВЕЩЕНСКИЙ, И. И., А. В. МАСЛЕННИКОВ, А. Н. МОРДВИНОВ, Н. С. РАКОВ, М. В. ШУСТОВ 1994. Флористико-экологические проблемы центральной части Приволжской возвышенности. - [Floristical and ecological problems in central part of the CisVolga Upland] Бот. Журн. [Bot. Zhurn.] 79(2): 5-13.

[BOBYLEVA, N. А.] БОБЫЛЕВА, Н. А. 1994. Накопление металлов в зеленых мхах в районе Костомукшского горнообогатительного комбината. - [The accumulation of metals in mosses in the area of Kostomuksha mining industrial complex] Ред. ж. Вестн. МГУ. Сер. 5. М., 1994, Деп. ВИНИТИ 12. 09. 1994, N 2177-В94. ["Vest. Mosk. Gos. Univ. Ser. 5." Moskva, 1994. Msc. Reserved in VINITI, 12. 09. 1994, N 2177-B94], 14.

[BOLYUKH, V. А.] БОЛЮХ, В. О. 1994. Радіоекологічний моніторинг мохоподібних. - [Radioecological monitoring of bryophytes] Укp. Бот. Журн. [Ukr. Bot. Zhurn.] 51(2/3): 172-178. 
[BOLYUKH, V. А.] БОЛЮХ, В. О. 1995. Екологоценотичні комплекси мохоподібних центральноі частини Поділля. - [Eco-coenotic complexes of bryophytes of Central part of Podolia] Укр. Бот. Журн. [Ukr. Bot. Zhurn.] 52(2): 206-213.

[BOLYUKH, V. А.] БОЛЮХ, В. О. 1995. Рідкісні мохоподібні Подільськоі височини. - [Rare bryophytes of Podolian Upland] Укр. Бот. Журн. [Ukr. Bot. Zhurn.] 52(4): 536-542.

[BOLYUKH, V. А.] БОЛЮХ, В. А. 1995. Сравнение флоры мхов центральной части Подолии (Украина) и сопредельных регионов. - [A comparison of moss flora of Central Podolia (Ukraine) and adjacent regions] Arctoa 4: 45-54.

[BOLYUKH, V. A. \& V. M. VIRCHENKO] БОЛЮХ, В. О., В. М. ВІРЧЕНКО 1994. Накопичення радіонуклідів мохами Украінського Полісся. - [Accumulation of radionuclides in mosses of the Ukrainian Polissya] У $_{k p}$. Бот. Журн. [Ukr. Bot. Zhurn.] 51(4): 39-45.

[BOTCH, M. S. \& E. O. KUZMINA] БОЧ, М. C., Е. О. КУЗЬМИНА 1994. Ритмика прироста некоторых видов рода Sphagnum L. в юго-западном Приладожье (Ленинградская область). - [The rhytmics of acrection and productivity of some species of mosses of the Sphagnum L. genus in the south-western vicinities of Ladoga Lake] Растительные ресурсы [Rastitel'nye recursy] 30(1-2): 135-142.

[BOTCH, M. S. \& V. A. SMAGIN] БОЧ, M. C., B. A. CMAГИН 1993. Флора и растительность болот северо-запада России и принципы их охраны. - [Flora and vegetation of mires in the north-west Russia and principles of their protection] СПб.,Гидрометеоиздат [StPetersburg, Gidrometeoizdat], 224.

[ВYСНЕК, І. А.] БЫЧЕК, И. А. 1994. Особенности распределения липидов в бриофитах: таксономический и экологический аспекты.- [Some peculiarities of li pid distribution in bryophytes: taxonomic and ecological aspects] Биохимия [Biokhimiya] 59(11): 1646-1662.

[CZERDANTSEVA, V. Үa.] ЧЕРДАНЦЕВА, В. Я. 1993. Листостебельные мхи. - [Mosses] Редкие виды растений Камчатской области и их охрана (ред. Клочкова, Н. Г.), Петропавловск-Камчатский, Дальневост. книжное из-во [In: Klochkova, N. G. (ed.) Redkie vidy rastenij Kamchatskoj oblasti i ikh ochrana, PetropavlovskKamchatskij, Dalnevost. Knizhnoe Izd-vo]: 136-151.

[CZERNYADJEVA, I. V.] ЧЕРНЯДЬЕВА, И. В. 1993. Листостебельные мхи среднего течения реки Сэбаяхи (Центральный Ямал). - [Leafy mosses in middle current of Sebayakha River (Central Yamal)] Бот. Журн. [Bot. Zhurn.] 78(11): 58-72.

[CZERNYADJEVA, I. V.] ЧЕРНЯДЬЕВА, И. В. 1994. Флора листостебельных мхов окрестностей стационара "Собь" (Полярный Урал). - [The moss flora of the region of Sob Station (Polar Ural)] Arctoa 3: 133-138.

[CZERNYADJEVA, I. V.] ЧЕРНЯДЬЕВА, И. В. 1994. Листостебельные мхи низовьев реки Чугорьяха (Югозападная часть Гыданского полуострова, Западносибирская Арктика). - [Mosses of the lower reaches of the Chugor'yakha River (south-western part of the Gydan Peninsula, West Siberian Arctic)] Бот. Журн. [Bot. Zhurn.] 79(8): 57-67.
[CZERNYADJEVA, I. V.] ЧЕРНЯДЬЕВА, И. В. 1995. К флоре листостебельных мхов полуострова Камчатка. - [On the moss flora of Kamchatka Peninsula] Бom. Журн. [Bot. Zhurn.] 80(6): 61-74.

[CZERNYADJEVA, I. V.] ЧЕРНЯДЬЕВА, И. В. 1995. Материалы к флоре листостебельных мхов окрестностей о3. Нгаранато (Центральный Ямал). - [Materials to the moss flora from surroundings of the Ngaranato Lake (Central Jamal)] Hовости сист. низи. pacm. [Novosti Sist. Nizsh. Rast.] 30: 136-139.

CZERNYADJEVA, I. V. 1995. Pohlia cardotii (Bryaceae, Musci) found in Eurasia (Russia, Kamtchatka Peninsula). - Ann. Bot. Fennici 32: 137-139.

CZERNYADJEVA, I. V. 1995. Philonotis yezoana Besch. et Card. ex Card. (Bartramiaceae, Musci) new to Russia. Arctoa 4: 15-16.

CZERNYADJEVA, I. V. \& M. S. IGNATOV 1993. Recent bryological literature of the former USSR. I. - Arctoa 2: 103-120.

[CZERNYADJEVA, I. V. \& L. E. KURBATOVA] ЧEPНЯДЬЕВА, И. В., Л. Е. КУРБАТОВА 1995. К флоре листостебельных мхов долины реки Поной (Кольский полуостров). - [On the flora of mosses of the River Ponoy (Kola Peninsula)] Вестник Петербургского ун-та. Сер. 3, вып. 2 [Vestnik Peterburzhskogo universiteta, Ser. 3, vyp. 2] 10: 56-62.

[CZERNYADJEVA, I. V. \& A. D. POTEMKIN] ЧEPНЯДЬЕВА, И. В., А. Д. ПОТЕМКИН 1993. К флоре мохообразных Центрального Ямала. - [On the bryoflora of Central Jamal] Новости сист. низи. раст. [Novosti Sist. Nizsh. Rast.] 29: 165-171.

[DARAGHAN, E. A. \& V. B. KUVAJEV] ДАРАГАН, Е. А., В. Б. КУВАЕВ 1994. Подкласс Sphagnidae - Сфагновые мхи. - [Subclass Sphagnidae] Растительный покров острова Сибирякова (Куваев, В. Б., А. Д. Кожевникова, С. В. Гудоиников, М. П. Журбенко, Э. Л. Нездойминого), Москва [In: Kuvајеv, V. B., A. D. Kozhevnikova, S. V. Gudoshnokov, M. P. Zhurbenko \& E. L. Nezdoiminogo, Rastitel'nij pokrov ostrova Sibiryakova, Moskva]: 30-32.

DEMBITSKI, V. M., T. REZANKA, I. A. BYCHEK \& O. M. AFONINA 1993. Acetylenic acids and lipid compositions of some mosses from Russia. - Phytochemistry 33(5): 1021-1027.

DEMBITSKI V. M., T. REZANKA, I. A. BYCHEK \& O. M. AFONINA 1993. Polar li pids and fatty acid composition of some bryophytes. - Phytochemistry 33(5): 1009-1014.

DEMBITSKY V. M., T. REZANKA, I. A. BYCHEK \& O. M. AFONINA 1994. Chemical constituents of some moss species. - J. Hattori Bot. Lab. 75: 161-172.

[DEMIDOVA, E. Е.] ДЕМИДОВА, Е. Е. 1993. Особенности устьичного аппарата сплахновых мхов. - [On the stomatal patterns in the Splachnaceae (Musci)] Arctoa 2: 49-55.

[DEMIDOVA, E. E. \& V. R. FILIN] ДЕМИДОВA, Е. Е., B. Р. ФИЛИН 1993. К морфологии и биологии сплахновых мхов. - [То the morphology and biology of Splachnaceae] ВИНИТИ, м., 1993. Деп. ВИНИТИ 01. 04. 1993, N 834-B93 [VINITI, Moskva, 1993. Msc. Reserved in VINITI, 01. 04. 1993, N 834-B93], 20. 
DEMIDOVA, E. E. \& V. R. FILIN 1994. False columella and spore release in Tetraplodon angustatus (Hedw.) Bruch et Schimp. in B. S. G. and T. mnioides (Hedw.) Bruch et Schimp. in B. S. G. (Musci: Splachnaceae).Arctoa 3: 1-6.

[DEMKIV, L. O.] ДЕМКИВ, Л. О. 1993. Сравнительное изучение влияния тяжелых металлов на мхи. - [The comparative research of the influence of heavy metals on the mosses] Труды IV молодежной конф. ботаников Санкт-Петербурга, ч. 5, май 1992. СПб., БИН РАН, Деn. ВИНИТИ 10. 06. 1993, N 1625-B93 [Trudy IV molodezhnoj konf. botanikov Sankt-Petersburg, Pt. 5, maj 1992. St-Petersberg, Bot. Inst. Ross. Akad. Nauk, Msc. Reserved in VINITI, 10. 06. 1993, N 1625-B93]: 22-30.

[DEMKIV, L. О.] ДЕМКІВ, Л. О. 1996. Реакціі мохів на токсичну дію важких металів. - [Moss reaction on toxicity of heavy metals] Автореф.... канд. биол. наук. Киів, Киівськ. Унів. [Thesis Ph. D. Kiev, Kievsk. Univ.], 22.

[DEMKIV, O. T. \& A. R. KARDASH] ДЕМКИВ, О. Т., А. Р. КАРДАШ 1994. Временная организация ветвления интеркалярных клеток протонемы и формирование почек гаметофоров у Funaria hygrometrica Hedw. - [The temporal organization of the intercalary cells branching and bud formation in the protonema of Funaria hygrometrica Hedw.] Изв. АН., сер. биолоzuч. [Izv. AN, ser. biol.] (1994) N 3: 411-418.

[DROZDOV, S. N., N. I. BALAGUROVA \& S. I. GRABOVIK] ДРОЗДОВ, С. Н., Н. И. БАЛАГУРОВА, С. И. ГРАБОВИК. 1994. Терморезистенстность видов рода Sphagnum (Sphagnaceae, Musci). - [Termoresistance of some Sphagnum (Sphagnaceae, Musci) species] Бom. Журн. [Bot. Zhurn.] 79(12): 29-34.

[DYACHENKO, А. Р.] ДЬЯЧЕНКО, А. П. 1995. История изучения флоры листостебельных мхов Приполярного Урала. - [History of the studies of moss flora in the Subarctic Urals] Arctoa 4: 17-22.

[DYACHENKO, А. Р.] ДЬЯЧЕНКО, А. П. 1996. К флоре листостебельных мхов полуострова Ямал. - [On moss flora of Yamal Peninsula] Флора и растительность Сибири и Дальнего Востока (чтения памяти Л. М. Черепнина; 2-я конференция). Красноярск, РБО и dp. [Flora i Rastitelnost Sibiri i Dalnego Vostoka (Chteniya pamyati L. M. Czerepnina; 2 konf.). Krasnoyarsk, Ross. Bot. Obshch. \& al.]: 61-62.

[DYACHENKO, A. P., E. A. IGNATOVA \& L. V. MARINА] ДЬЯЧЕНКО, А. П., Е. А. ИГНАТОВА, Л. В. МАРИНА 1996. Список листостебельных мхов Висимского заповедника. - [Moss flora of the Visimskij State Reserve] Проблемы заповедного дела (25 лет Висимскому заповеднику - Мат. научн. конф.) (ред. Ю. Ф. Марин), Екатеринбург, Висимский заповедник [In: Marin, Yu. F. Problemy zapovednogo dela (25 let Visimskomu zapovedniku - Mat. konf.), Ekaterinburg, Visimskij Zapovednik]: 42-44.

[DYACHENKO, A. P., A. L. VASINA \& M. I. GAVRILOV] ДЬЯЧЕНКО, А. П., А. Л. ВАСИНА, М. И. ГАВРИЛОВ. 1995. Флора листостебельных мхов заповедника "Малая Сосьва" (Западная Сибирь). - [Moss flora of the Malaya Sosva State Reserve (West Siberia)] Arctoa 5: 35-38.
[DYACHENKO, A. P., A. L. VASINA \& M. I. GAVRILOV] ДЬЯЧЕНКО, А. П., А. Л. ВАСИНА, М. И. ГАВРИЛОВ 1991. Листостебельные мхи заповедника "Малая Сосьва". - [Mosses of the Malaya Sosva State Reserve] Флора и растительность Сибири и Дальнего Востока (чтения памяти Л. М. Черепнина). Красноярск, ВБО и дp. [Flora i Rastitelnost Sibiri i Dalnego Vostoka (Chteniya pamyati L. M. Czerepnina). Krasnoyarsk, Vsesoyuznoe Bot. Obshch. \& al.]: 24-26.

[GAMBARYAN, S. К] ГАМБАРЯН, С. К. 1993. Состояние изученности печеночных мхов юга Дальнего Востока России. - [State of knowledge of the liverworts in the south of the Russian Far East] Владивосток, Дальнаукa [Vladivostok, Dalnauka], 23.

[GAMBARYAN S. К.] ГАМБАРЯН, С. К. 1994. Изучение редких видов печеночников охраняемых и заповедных территорий Приморского края. - [Study of rare species of liwerworts in the protected and reserved regions of the Primoryj Territory] Материалы совещания "Природоохранные территории и акватории Дальнего Востока и проблемы сохранения биологического разнообразия" (ред. Абрамов, В. К. и др.). Владивосток, Биол.-Почв. ин-т ДВО РАН [In: Abramov, V. K. \& al. (eds.) Materialy soveshchaniya "Prirodoochrannye territorii $i$ akvatorii Dal'nego Vostoka $i$ problemy sochraneniya biologicheskogo rasnoobraziya". Vladivostok, Biol.-Pochv. Inst. Dalnevost. Otd. Ross. Akad. Nauk]: 82-87.

[GAPON, S. V.] ГАПОН, С. В. 1992. Мохоподібні лівобережного лісостепу Украіни. - [The bryophytes of the left-bank forest-steppes of Ukraina] Aвmopepeрат... канд. биол. наук, Киів, Інст. Бот. АНУ [Ph. D. Thesis, Kiev, Inst. Bot. Akad. Nauk. Ukr.], 22.

[GRABOVIK, S. I.] ГРАБОВИК, С. И. 1994. Влияние климатических условий на линейный прирост сфагновых мхов в Южной Карелии. - [The effect of climatic conditions on the linear increment of Sphagnum mosses on Southern Karelia] Бот. Журн. [Bot. Zhurn.] 79(4): 81-86.

[GUDOSHNIKOV, S. V. \& V. B. KUVAJEV] ГУ ДОШНИКОВ, С. В., В. Б. КУВАЕВ 1994. Подкласс Andreaeidae - Андреевые мхи. - [Subclass Andreaeidae] Растительный покров острова Сибирякова (Куваев, В. Б., А. Д. Кожевникова, С. В. Гудошников, М. П. Журбенко, Э. Л. Нездойминого), Москва [In: Kuvajev, V. B., A. D. Kozhevnikova, S. V. Gudoshnokov, M. P. Zhurbenko \& E. L. Nezdoiminogo, Rastitel'nij pokrov ostrova Sibiryakova, Moskva]: 32.

[GUDOSHNIKOV, S. V. \& V. B. KUVAJEV] ГУ ДОШНИКОВ, С. В., В. Б. КУВАЕВ 1994. Подкласс Bryidae - Бриевые мхи. - [Subclass Bryidae - Bryidae mosses] Растительный покров острова Сибирякова (Куваев, В. Б., А. Д. Кожевникова, С. В. Гудошников, М. П. Журбенко, Э. Л. Нездойминого), Москва [In: Kuvajev, V. B., A. D. Kozhevnikova, S. V. Gudoshnokov, M. P. Zhurbenko \& E. L. Nezdoiminogo, Rastitel'nij pokrov ostrova Sibiryakova, Moskva]: 32-43.

IGNATOV, M. S. 1993. Moss diversity patterns on the territory of the former USSR. - Arctoa 2: 13-47.

IGNATOV, M. S. 1994. Bryophytes of Altai Mountains. I. Study area and history of its bryological exploration. Arctoa 3: 13-27. 
IGNATOV, M. S. \& CAO TONG 1994. Bryophytes of Altai Mountains. IV. The family Grimmiaceae (Musci). - Arctoa 3: 67-122.

IGNATOV, M. S. \& V. Ya. CZERDANTSEVA 1995. The families Cryphaeaceae, Leucodontaceae and Leptodontaceae (Musci) in Russia. - Arctoa 4: 65-104.

[IGNATOV, M. S. \& E. A. IGNATOVA] ИГНАTOB, М. C., Е. А. ИГНАТОВА 1993. Мхи Пинежского заповедника [Mosses of Pinega Reserve]. - Бюлл. Главн. бот. сада [Byull. Glawn. Bot. Sada] 167: 36-47.

IGNATOV, M. S. \& J. LEWINSKY-HAAPASAARI 1994. Bryophytes of Altai Mountains. II. The genera Amphidium Schimp., Orthotrichum Hedw. and Zygodon Hook. \& Tayl. (Orthotrichaceae, Musci). - Arctoa 3: 29-57.

IGNATOV, M. S. \& R. OCHYRA 1994. Bryophytes of Altai Mountains. III. The genus Ulota (Orthotrichaceae, Musci). - Arctoa 3: 59-66.

IGNATOV, M. S. \& R. OCHYRA 1995. On the systematic position of Myurella and Bardunovia, genus novus (Plagiotheciaceae, Musci). - Arctoa 5: 45-59.

IGNATOV, M. S. \& G. L. SMITH MERRILL 1995. Bryophytes of Altai Mountains. VI. The Family Polytrichaceae (Musci). - Arctoa 5: 61-97.

IGNATOV, M. S. \& R. H. ZANDER 1993. Barbula amplexifolia from the Altai Mountains of Russia. - Bryologist 96(4): 638-639.

[IGNATOV, M. S. \& N. I. ZOLOTUKHIN] ИГНАTOB, М. С., Н. И. ЗОЛОТУХИН 1994. О редких мхах Алтайского заповедника. - [On rare mosses of Altaian State Reserve] Растения Красных книг в заповедниках России (ред. Ю. Д. Нухимовская), М., ЦНИЛОХЗ [In: Nukhimovskaya, Yu. D. (ed.) Rasteniya Krasnykh knig v zapovednikakh Rossii, Moskva]: 158-161.

IGNATOVA, E. A., M. S. IGNATOV \& A. G. BEZGODOV 1995. Moss flora of the Basegi State Reserve (Perm Province, Middle Ural Mountains). - Arctoa 4: 23-34.

INGERPUU, N., A. KALDA, L. KANNUKENE, H. KRALL M. LEIS \& K. VELLAK 1994. List of the Estonian Bryophytes. - Tartu, Acad. Sci. Estonia, 175.

INGERPUU, N. \& K. VELLAK 1995. The distribution and some ecological characteristics of Estonian rare bryophytes. - Arctoa 5: 143-148.

[JUKONIENE, I.] ЮКОНЕНЕ, И. 1993. Листостебельные мхи (Bryopsida) Литвы. - [Lietuvos lapsamanes (Bryopsida) - Mosses of Litva] Ph. D. Thesis, Vilnius, Lietuvos Rep. Bot. Inst., 28.

[KAZANOVSKY, S. G.] КАЗАНОВСКИЙ, С. Г. 1993. Эпифитные мохообразные хребта Хамар-Дабан. - [The epi phytic bryoflora of Khamar-Daban Range] Tруды IV молодежной конф. ботаников Санкт-Петербур2a, ч. 5, май 1992. СПб., БИН РАН Деп. ВИНИТИ 10.VI.1993, N 1625-B93 [Trudy IV molodezhnoj konf. botanikov Sankt-Petersburg, Pt. 5, Maj 1992. St-Petersburg, Bot Inst. Ross. Akad. Nauk, Msc. Reserved in VINITI, 10.VI.1993, N 1625-B93]: 45-59.

[KAZANOVSKY, S. G.] КАЗАНОВСКИЙ, С. Г. 1993. Бриофлора хребта Хамар-Дабан (Южное Прибайкалье). - [The bryoflora of Khamar-Daban Range (Southern Baikal Region)] Автореф.... канд. биол. наук. Ново- сибирск, ЦСБС [Thesis Ph. D. Novosibirsk, Centr. Sib. Bot. Sad], 16.

[KAZANOVSKY, S. G. \& A. D. POTEMKIN] KA3AHOBСКИЙ, С. Г., А. Д. ПОТЕМКИН 1995. К флоре печеночных мхов хребта Хамар-Дабан (Южное Прибайкалье). - [On the flora of liverworts of the KhamarDaban Range (Southern Baikal Region)] Новости сист. низи. pacm. [Novosti Sist. Nizsh. Rast.] 30: 98-110.

[KHORKAVTSIV, Ya. D., O. R. KARDASH \& O. T. DEMKIV] ХОРКАВЦІВ, Я. Д., О. Р. КАРДАШ, О. Т. ДЕМКІВ 1994. Динаміка внутрішньоклітинного кальцію і pH під час регенераціі ізольованих клітин. - [Dynamics of the intracellular $\mathrm{Ca}^{2+}$ and $\mathrm{pH}$ during regeneration of isolated cells] Укр. Бот. Журн. [Ukr. Bot. Zhurn.] 51(4): 81-88.

[KONSTANTINOVA, N. A., O. A. BELKINA \& A. Yu. LIKHACHEV] КОНСТАНТИНОВА, Н. А., О. А. БЕЛКИНА, А. Ю. ЛИХАЧЕВ 1993. Эксикаты мохообразных Мурманской области. Часть II. - [Bryophyta Murmanica Exiccata (USSR). II] Кировск [Kirovsk], 22.

[KONSTANTINOVA, N. A. \& I. V. CZERNYADJEVA] КОНСТАНТИНОВА, Н. А., И. В. ЧЕРНЯДЬЕВА 1995. Печеночники среднего течения р. Собь (Полярный Урал). - [Liverworts of Middle Sob River (Polar Urals)] Новости сист. низи. pacm. [Novosti Sist. Nizsh. Rast.] 30: 110-121.

[KONSTANTINOVA, N. A. \& V. B. KUVAJEV] KOHСТАНТИНОВА, Н. А., В. Б. КУВАЕВ 1994. Класс Hepaticae (Hepaticopsida) - Печеночники . - [Class Hepaticae (Hepaticopsida) - (Liverwort)] Растительный покров острова Сибирякова (Куваев, В. Б., А. Д. Кожевникова, С. В. Гудошников, М. П. Журбенко, Э. Л. Нездойминого), Москва [In: Kuvајеv, V. B., A. D. Kozhevnikova, S. V. Gudoshnokov, M. P. Zhurbenko \& E. L. Nezdoiminogo, Rastitel'nij pokrov ostrova Sibiryakova, Moskva]: 27-30.

[KONSTANTINOVA, N. A., A. Yu. LIKHACHEV \& O. A. BELKINA] КОНСТАНТИНОВА, Н. А., А. Ю. ЛИХАЧЕВ, О. А. БЕЛКИНА 1993. Дополнения и уточнения к "Конспекту флоры мохообразных Мурманской области". - [Additions and refinements to "Synopsis of the Bryophyte of the Murmansk region"] Флористические u геоботанические исследования в Мурманской области (ред. Н. А. Константинова), Anатиты [In: Konstantinova, N. A. (ed.) Floristicheskie i geobotanicheskie issledovaniya v Murmanskoj oblasti. Apatity]: 6-44.

KONSTANTINOVA, N. A. \& A. D. POTEMKIN. 1993 Studies on Scapania sphaerifera (Hepaticae). - Ann. Bot. Fennici 31: 121-126.

KONSTANTINOVA, N. A. \& A. N. VASILJEV 1994. On the hepatic flora of Sayan Mountains (South Siberia). Arctoa 3: 123-132.

[KOZHEVNIKOV Yu. P., M. P. ZHURBENKO \& O. M. AFONINA] КОЖЕВНИКОВ Ю. П., М. П. ЖУРБЕНКО, О. М. АФОНИНА 1994. Растительный покров островов Свердруп и Тройной (Карское море). - [Vegetation of Trynoy and Sverdrup Islands (Kara Sea)] Арктические тундры Таймыра и островов Карского моря (ред. Э. В. Рогачева) Москва, РАН, Институт проблем экологии и эволющии и др. [In: Rogacheva, E. V. (ed.) Arcticheskie tundry Tajmyra i ostrovov 
Karskogo morya. Moskva, Inst. Problem Ekol. i Evol. Ross. Akad. Nauk \& al.] 2: 121-143.

[KUZMINA, E. YU.] КУЗЬМИНА, Е. Ю. 1993. Экологоценотическая характеристика листостебельных мхов на северо-востоке Корякского нагорья. - [Ecologocoenotical haracter of the mosses in the north-east of Koryakskoye Upland] Труды IV молодежной конф. ботаников Санкт-Петербурга, ч. 5, май 1992. СПб., БИН РАН, Деп. ВИНИТИ 10. 06. 1993, N 1625-В93 [Trudy IV molodezhnoj konf. botanikov Sankt-Petersburg, Ch. 5, maj 1992. St-Petersburg, Bot. Inst. Ross. Akad. Nauk, Msc. Reserved in VINITI, 10. 06. 1993, N 1625-B93]: 105-109.

[KUZMINA, Е. YU.] КУЗЬМИНА, Е. Ю. 1995. Флора листостебельных мхов северо-востка Корякского нагорья. - [The moss flora of north-east of Koryakskoye Upland] Hовости сист. низи. pacm. [Novosti Sist. Nizch. Rast.] 30: 121-128.

[KUZMINA, E. YU.] КУЗЬМИНА, Е. Ю. 1995. Дополнение к флоре листостебельных мхов Корякского нагорья. - [Supplement to the moss flora of Koryakskoye Upland] Труды $V$ молодежной конф. ботаников в Санкт-Петербурге (Росков, Ю. Р., С. И. Чубаров, pед.). СПб., БИН РАН [In: Roskov, Yu. R. \& S. I. Chubarov (ed.) Trudy V molodezhnoj konf. botanikov $v$ Sankt-Petersburge. St.-Petersburg, Bot. Inst. Ross. Akad. Nauk]: 67-69.

[LOBACHEVSKA, O. V. \& K. O. ULYCHNA] ЛОБАЧЕВСЬКА, О. В., К. О. УЛИЧНА. 1994. Гібридна популяція моху Tortula canescens Mont. Ч Т. muralis Hedw. 3 околиць м. Миколаэва (Львівська обл.). [Pecularities of hybridous population of moss Tortula canescens Mont. Ч Tortula muralis Hedw. from vicinities of Nicolaev (Lviv Province)] Укр. Бот. Журн. [Ukr. Bot. Zhurn.] 51(6): 84-92.

[LOTAREVA, O. V.] ЛОТАРEBA, О. В. 1993. Индукция каллюсной и суспензионной культур клеток мха Polytrichum commune и некоторые особенности их культивирования. - [The induction of callus and suspension culture of cells of moss Polytrichum commune and some peculiarity their cultivation] Изв. АН, сер. биол. (Россия) [Izv. AN, ser. biol. (Russia)] 1: 152-155.

MAKSIMOV, A. 1995. New data on the distribution of Sphagnum molle in Karelia (Russia). - Memoranda Soc. Fauna Flora Fennica 71(1-2): 1-2.

[MAKSIMOV, А. I.] МАКСИМОВ, А. И. 1995. Мхи. [Mosses] Красная книга Карелии (ред. Ивантер, Э. В., О. Л. Кузнечов) Петрозаводск, “Карелия” [Іп: Ivanter, Ae. V. \& O. L. Kuznetsov (eds.) Krasnaya kniga Karelii. Petrozavodsk, "Kareliya"]: 75-88.

[MANAKYAN, V. А.] МАНАКЯН, В. А. 1995. Итоги бриологических исследований в Армении. - [Results of bryological studies in Armenia] Arctoa 5: 15-33.

[MORDVINOV, A. N.] МОРдВИНОВ, А. Н. 1993. Бриофлора центральной части Приволжской Возвышенности. - [Bryoflora of the central part of Pryvolzhskaja Upland] Автореферат... канд. биол. наук, Новосибирск, ЦСБС [Ph. D. Thesis, Novosibirsk, Centr. Sib. Bot. Sad], 16.

[MORDVINOV, A. N.] МОРдВИНОВ, А. Н. 1994. Бриофлора Жигулевского заповедника. - [The bryoflora of Zigulyovsky Reserve] Бот. журн. [Bot. Zhurn.] 79(4): $65-70$.

[MORDVINOV, A. N.] МОРДВИНОВ, А. Н. 1994. Бриофлора степных сообществ центральной части Приволжской возвышенности. - [The bryoflora of the steppe community of central part of Pryvolzhskaya Upland] Актуальные вопросы экологии и охрань природы степных экосистем и сопредельных территорий, Краcнодар [Aktual'nye voprosy ekologii i ochrany prirody stepnykh ecosistem i sopredel'nykh territorij, Krasnodar]: 58-62.

[MORDVINOV, A. N.] МОРДВИНОВ, А. Н. 1995. Бриофлора болотных сообществ центральной части Приволжской возвышенности. - [The bryoflora of the peatlands of central part of Pryvolzhskaya Upland] Актуальные вопросы экологии и охраны природы водных экосистем и сопредельных территорий, Краснодар. [Aktual'nуе vоprosy ekologii $i$ ochrany prirody vodnykh ecosistem $i$ sopredel'nykh territorij, Krasnodar]: 80-82.

[MORDVINOV, A. N.] МОРДВИНОВ, А. Н. 1995. Моховой покров сосновых лесов центральной части Приволжской возвышенности. - [The moss cover of the pine forests of central part of Pryvolzhskaja Upland] Флористические исследования в Центральной России. Мат. науч. конф. “Флора Центральной России”, Липецк, 1 3 февраля 1995 г. (ред. Тихомиров, В. Н.). М., МОИП u $\partial p$. [In: Tikhomirov, V. N. (ed.) Floristicheskie issledovaniya v Tsentralnoj Rossii. Mat. nauch. konf. "Flora Centralnoj Rossii”, Lipetsk, 1-3 fevralya 1995, Moskva, Mosk. Obshch. Ispyt. Prir. \& al.]: 143-145.

[MORDVINOV, A. N. \& I. V. BLAGOVESHCHENSKYI] МОРДВИНОВ, А. Н., И. В. БЛАГОВЕЩЕНСКИЙ. 1995. Флора мохообразных Ульяновской области. [The bryoflora of Ulyanovsk Province] Ульяновск, РАН u dp. [Ul'yanovsk, Ross. Akad. Nauk \& al.], 88.

[MULDIYAROV, E.Ya., A. I. PYAK, A. L. EBEL] МУЛЬДИЯРОВ, Е. Я., А. И. ПЯК, А. Л. ЭБЕЛЬ 1996. Новые для флоры Томской области виды мохообразных и сосудистых растений. - [The new species of mosses and vascular plants for flora of the Tomsk Region] Бот. Журн. [Bot. Zhurn.] 81(5): 90-93.

NAUJALIS, J., N. KALINAUSKAITE \& M. GRINEVICIENE 1995. Vadovas Lietuvos kerpsamanems pazinti. - [A Guide-book for recognition of Liverworts in Lithuania] Vilnius, Zodynas, 244.

[NOTOV, A. A.] HOTOB, А. А. 1994. О некоторых новых и редких для Тверской области видах мохообразных. - [On some new and rare bryophytes from Tver' Province] Флора и растительность Тверской области (ред. М. В. Марков). Тверь, Тверской гос. ун-т [In: Markov, M. V. (ed.) Flora i rastitelnost' Tverskoi Oblasti. Tver', Tverskoj Gos. Univ.]: 24-31.

OCHYRA, R. \& O. M. AFONINA 1995. Schistidium cryptocarpum (Musci, Grimmiaceae) in the Russian Arctic. - Fragm. Flor. Geobot. 40(1): 215-221.

[PARTYKA, L. Үа.] ПАРТИКА, Л. Я. 1994. Мохоподібні природно-заповідних територій Центральноі частини Південного берега Криму. - [Bryophyta of nature reservation territories in the central part of the South Coast of Crimea] Укр. Бот. Журн. [Ukr. Bot. Zhurn.] 51(2) 3): $217-224$. 
[PARTYKA, L. Ya.] ПАРТИКА, Л. Я. 1995. Бріофлора Ялтинського гірсько-льсового природного заповідника. - [Bryoflora of Yalta mountain-forest natural reserve] Укр. Бот. Журн. [Ukr. Bot. Zhurn.] 52(2): 260-270.

[POPOVA, N. N.] ПОПОВА, Н. Н. 1994. Дополнения к бриофлоре бассейна Среднего Дона. - [Additions to the bryoflora of the basin of the Middle reaches of the Don River] Бот. Журн. [Bot. Zhurn.] 79(10): 133-137.

[POPOVA, N. N.] ПОПОВА, Н. Н. 1994. Характеристика некоторых эпифитных бриосинузий Усманского бора. - [The characteristics of some epiphytic bryosynusions of the Usmanskiy pine forest] Состояние и проблемы экосистем Усманского бора (ред. Простаков, Н. И.). Воронеж, Воронежский гос. ун-т [In: Prostakov, N. I. (ed.). Sostoyanie i problemy ekosistem Usmanskogo bora. Voronezh, Voronezhskij Gos. Univ.]: 188-191.

[POPOVA, N. N.] ПОПОВА, Н. Н. 1994. Характеристика травяно-мохового покрова сосняков на экологическом профиле Усманского бора. - [The characteristics of herb-moss layer of pine forests in trasect in Usmanskij pine forest] l.c.: 128-135.

[POPOVA, N. N.] ПОПОВА, Н. Н. 1995. Новинки бриофлоры Воронежской области. - [New species of the bryoflora of Voronezh region] Флористические исследования в Центральной России. Мат. науч. конф. “Флора Центральной России”, Липецк, 1-3 февраля 1995 г. (ред. Тихомиров, В. Н.). М., МОИП и др. [In: Tikhomirov, V. N. (ed.) Floristicheskie issledovaniya v Tsentralnoj Rossii. Mat. nauch. konf. "Flora Centralnoj Rossii”, Lipetsk,1-3 fevralya 1995, Moskva, Mosk. Obshch. Ispyt. Prir. \& al.]: 145-148.

[POPOVA, N. N.] ПОПОВА, Н. Н. 1995. Мохообразные. - [Mosses] Природа Лысых гор, нового заповедного участка в Белгородской области. Тр. ЦентральноЧерноземного государственного заповедника, вып. 14. M., КМК [Priroda Lysykh Gor, novogo zapovednogo uchastka v Belgorodskoj oblasti. Tr. CentralnoChernozemnogo Gos. Zapovednika, vyp. 14. Moskva, KMK]: 25-29.

[POPOVA, N. N.] ПОПОВА, Н. Н. 1995. Репрезентативность бриофлоры заповедных объектов Центрального Черноземья. - [Representation of bryophytes in protected territories in Central Cernozem Region] Проблемы изучения и охраны заповедных природных комплексов (Мат. конф., Варварино Воронежской обл., 21-25 августа 1995) (ред. Зобов, А. И.) Воронеж, Изд-во Воронежск. ун-та [In: Zobov, A. I. (ed.) Problemy izucheniya $i$ okhrany zapovednykh prirodnykh kompleksov (Mat. konf., Varvarino, Voronezhskaya Obl., 21-25 avgusta 1995) Voronezh, Izd. Voronezh. Univ.]: 160-161.

[POPOVA, N. N.] ПОПОВА, Н. Н. 1995. Материалы к флоре мохообразных Орловской области. - [Contribution to bryophyte flora of Orel Province] Проблемы сохранения разнообразия природы степных и лесостепных регионов (Мат. конф. 22-27 мая 1995, Курская обл., пос. Заповедный)(ред. Золотухин, Н. И.), М., КМК [In: Zolotukhin, N. I. (ed.) Problemy sokhraneniya raznoobraziya pripody stepnykh i lesostepnykh regionov (Mat. conf. 22-27 maya 1995, Kurskaya Obl., pos. Zapovednyj), Moskva, KMK]: 136-137.
[POPOVA, N. N.] ПОПОВА, Н. Н. 1995. К оценке влияния природных факторов на разнообразие бриофитов охраняемых лесостепных экосистем. - [On the evaluation of influence of natural factors on bryophyte diversity in protected forset-steppe ecosystems] Проблемы сохранения разнообразия природы степных и лесостепных регионов (Мат. конф. 22-27 мая 1995, Курская обл., пос. Заповедный)(ред. Золотухин, H. И. ), М., КМК [In: Zolotukhin, N. I. (ed.) Problemy sokhraneniya raznoobraziya pripody stepnykh $i$ lesostepnykh regionov (Mat. conf. 22-27 maya 1995, Kurskaya Obl., pos. Zapovednyj), Moskva, KMKJ: 138-139.

[POPOVA, N. N. \& V. I. ZOLOTOV] ПОПOBA, H. H., В. И. ЗОЛОТОВ 1995. О некоторых редких и интересных видах бриофлоры Посеймья. - [About some rare and interesting species of the bryoflora of Posemy] Флористические исследования в Центральной России. Мат. науч. конф. “Флора Центральной России”, Липецк, 1-3 февраля 1995 г. (ред. Тихомиров, В. Н.). M., МОИП и др. [In: Tikhomirov, V. N. (ed.) Floristicheskie issledovaniya v Tsentralnoj Rossii. Mat. nauch. konf. "Flora Centralnoj Rossii", Lipetsk, 1-3 fevralya 1995, Moskva, Mosk. Obshch. Ispyt. Prir. \& al. ]: 148-150.

POTEMKIN, A. D. 1993. The Hepaticae of the Yamal Peninsula, West Siberian Arctic. - Arctoa 2: 57-101.

[POTEMKIN, A. D.] ПОТЕМКИН, А. Д. 1993. Заметки о внутривидовой таксономии, размножении и синонимике Scapania scandica (H. Arn. et Buch) Macv. (по ямальским материалам). - [Notes on infraspecific taxonomy, reproduction and synonymy of Scapania scandica (H. Arn. et Buch) Macv. (on the basis of the Yamal materias)] Новости сист. низи. pacm. [Novosti Sist. Nizsh. Rast.] 29: 153-157.

[POTEMKIN, A. D.] ПОТЕМКИН, А. Д. 1993. О размножении некоторых печеночников. - [On reproduction of some hepatics] Новости сист. низи pacm. [Novosti Sist. Nizsh. Rast.] 29: 145-152.

[POTEMKIN. A. D.] ПОТЕМКИН, А. Д. 1994. Печеночные мхи низовьев реки Чугорьяха (Юго-Западная часть Гыданского полуострова, Западносибирская Арктика). - [The liverworts of the lower reaches of the Chugoryakha River (South-western part of the Gydan Peninsula, West Siberian Arctic)] Бот. Журн. [Bot. Zhurn.] 79(8): 51-57.

POTEMKIN, A. D. 1994. Studies on Scapania, Hepaticae. Sectio Rufidulae and sectio Nemorosae. - J. Hattori Bot. Lab. 77: 273-285.

POTEMKIN, A. D. 1995. К флоре печеночных мхов Ленинградской области. Новые и малоизвестные таксоны. II. - [On the flora of liverwort of the Leningrad Province. Taxa new and little-known. II] Hовости сист. низи. pacm. [Novosti Sist. Nizsh. Rast.] 30: 128-136.

POTEMKIN, A. D. \& S. G. KAZANOVSKY 1993. On the genus Mylia S. Gray (Hepaticae, Jungermanniaceae, Mylioideae). - Arctoa 2: 1-11.

POTEMKIN, A. D. \& N. A. KONSTANTINOVA 1995. Rare liverworts of the Russian Arctic - a preliminary list and directions for future research. - Crytogamica Helvetica 18: 43-50. 
[POTEMKIN, A. D. \& I. V. TCHEREPANOV] ПOTEMКИН, А. Д., И. В. ЧЕРЕПАНОВ 1993. К флоре печеночных мхов Ленинградской области. Новые и малоизвестные для области таксоны. - [On the flora of liverworts of the Leningrad Province. Taxa little-known and new for the province] Новости сист. низи. раст. [Novosti Sist. Nizsh. Rast.] 29: 158-165.

[REBRISTAYA, O. V., O. V. KHITUN \& I. V. CZERNYADJEVA] РЕБРИСТАЯ, О. В., О. В. ХИТУН, И. В. ЧЕРНЯДЬЕВА 1993. Техногенные нарушения и естественное восстановление растительности в подзоне северных гипоарктических тундр полуострова Ямал. - [Technogenous disturbances and natural reestablishment of vegetation in the subzones of the northern hypoarctictundras of the Yamal Peninsula] Бот. Журн. [Bot. Zhurn.] 78(3): 122-135.

[REBRISTAYA, O. V., O. V. KHITUN, I. V. CZERNYADJEVA, М. О. LЕIBMAN] РЕБРИСТАЯ, О. В., О. В. ХИТУН, И. В. ЧЕРНЯДЬЕВА, М. О. ЛЕЙБМАН 1995. Динамика растительности на криогенных оползнях в центральной части полуострова Ямал. - [Dynamics of vegetation on the cryogenic landslips in the central part of the Yamal Peninsula] Бот. Журн. [Bot. Zhurn.] 80(4): 31-48.

RUI-LIANG ZHU, REN-LIANG HU \& YI-JIE MA 1994. Some Comments on Rare and Endangered Liwerworts in Mainland China. - Arctoa 3: 7-12.

[RIPETSKY, R. T. \& N. A. КІT] РІПЕЦЬКИЙ, Р. T., Н. А. КІT. 1994. Інтенсивність флуоресценціі хлорофілу клітин гаметофіта моху Pottia intermedia (Turn.) Furnr. під впливом висушування. - [The effect of a desiccation on the fluorescence of chlorophyll of the moss gametophyte cells of Pottia intermedia (Turn.) Furnr.] Укр. Бот. Журн. [Ukr. Bot. Zhurn.] 51(4): 144-145.

[RYKOVSKY, G. F.] РЫКОВСКИЙ, Г. Ф. 1991. О происхождении антоцеротовых (Anthocerotopsida). - [About the origin of Anthocerotae (Anthocerotopsida)] Филогения и систематика растений (ред. Тихомиров, В. Н.), M., Наука [In: Tikhomirov, V. N. (ed.), Filogeniya $i$ sistematika rastenij, Moskva, Nauka]: 94-96.

[RYKOVSKY, G. F.] РЫКОВСКИЙ, г. Ф. 1993. Происхождение мохообразных как группы архегониальных (высших) растений. - [The origin of bryophytes as a group of archegoniate (higher plants)] Проблемь ботаники. Материалы VI делегатского съезда Белорусского республиканского ботанического общества.Ч. 1 (ред. Парфенов, В. И.) Минск [In: Parfenov, V. I. (ed.) Problemy botaniki. Materialy VI delegetskogo s'ezda Belorusskogo respublikanskogo botanicheskogo obshchestva. Ch. 1, Minsk]: 70-78.

[RYKOVSKY, G. F.] РЫКОвСКИЙ, Г. Ф. 1995. Происхождение и эволюция мохообразных с оценкой современного состояния и генезися бриофлоры. [Origin and evolution of bryophytes, with evaluation of contemporary condition and genesis of bryoflora] Автореф.... докт. биол. наук. Минск, ИЭБ [Thesis Ph. D., Minsk, Inst. Experim. Bot.], 35.

[RYKOVSKY, G. F. \& I. P. JUKONIENE] РЫКОВСКИЙ, Г. Ф., И. П. ЮКОНЕНЕ 1991. Флора мохообразных растений. - [Flora of bryophytes] Состояние наземных фитоценозов в зоне Игналинской АЭС в предпу- сковой период (ред. Лякавичюс, A), Вильнюс, Моксrac [In: Lekavicius, A (ed.) Sostoyanie nazemnykh fitotsenozov v zone Ignalinckoj AES v predpuskovoj period, Vilnus, Mokclas]: 166-187.

[SCHLJAKOV, R. N.] ШЛЯКОВ, Р. Н. 1995. Еще раз о "Bryum schleicheri var. latifolium" (Bryopsida, Bryaceae). - [Once again on "Bryum schleicheri var. latifolium" (Bryopsida, Bryaceae)] Бот. Журн. [Bot. Zhurn.] 80(6): 94-102.

SCHUSTER, R. M. \& N. A. KONSTANTINOVA 1996. Studies on the distribution of critical arctic/subarctic Hepaticae with special reference to taxa found in Russia. - Lindbergia 21: 26-48.

[SHUBINA, T. P. \& G. V. ZHELEZNOVA] ШУБИНА, Т. П., Г. В. ЖЕЛЕЗНОВА. 1995. К флоре листостебельных мхов Мезенско-Вычегодской равнины (Республика Коми). [On the moss flora of the Mezensko-Vychegodskaya Plain (Komi Republic)] Arctoa 5: 39-44.

[SLUKA, Z. А.] СЛУКА, З. А. 1993. Мхи-эпифиты в зеленых массивах на территории Москвы. - [The еріphytic mosses in green massif of Moskow] Биол. науки [Biol. nauki] (1993) N 2: 39-46.

[SLUKA, Z. А.] СЛУКА, 3. А. 1993. Бриофлора в зеленых массивах г. Москвы. - [Bryoflora of Moscow Parklands] Вестник МГУ, сер. биол. [Vestnik MGU, ser. biol.] (1993) N 4: 30-38.

[SLUKA, Z. А.] СЛУКА, 3. А. 1994. Редкие виды мхов на территории Москвы. - [Rare bryophytes in Moscow territory] Вестник МГУ, сер. биол. [Vestnik $M G U$, ser. biol.] (1994) $\mathrm{N}$ 4: 38-44.

[STEPANOVA, N. A.] СТЕПАНОВА, Н. А. 1991. Мохообразные. - [Bryophytes] Флора тундровой зоны Якутии (ред. Тимофеев, П. А.) Якутск, ЯНЦ СО АН CCCP. [In: Timofeev, P. A. (ed.) Flora tundrovoj zony Yakutii. Yakutsk, Yakut. Nauchn. Cantr Sib. Otd. Akad. Nauk SSSR]: 69-87.

[STEPANOVA, N. A. \& E. I. IVANOVA \& K. A. VOLOTOVSKY] СТЕПАНОВА, Н. А., Е. И. ИВАНОВА, К. А. ВОЛОТОВСКИЙ. 1995. Материалы к изучению бриофлоры хребта Токинский Становик (Южная Якутия, Восточная Сибирь). - [Contributions to the bryoflora of Tokinskij Stanovik range (South Yakutia, East Siberia)] Arctoa 4: 35-44.

TAN, B. C., J.-C. ZHAO \& R.-L. HU. 1995. An updated checklist of mosses of Xinjiang, China. - Arctoa 4: 1-14.

[TARASOVA, I. V.] TAPACOBA, И. В. 1993. Листостебельные мхи западных предгорий Кузнецкого Алатау. - [The mosses from western foothills of Kuznetsk Alatau] Tруды IV молодежной конф. ботаников Санкт-Петербурга, ч. 5, май 1992. СПб., БИН РАН, Деп. ВИНИТИ 10.VI.1993, N 1625-B93 [Trudy IV molodezhnoj konf. botanikov Sankt-Petersburga, Pt. 5 , maj 1992. St-Petersberg, Bot. Inst. Ross. Akad. Nauk, Msc. Reserved in VINITI, 10.VI.1993, N 1625-B93]: 134-141.

[UKRAINSKAYA, G. Үa.] УКРАИНСКАЯ, Г. Я. 1996. Plagiothecium berggrenianum (Plagiotheciaceae, Musci) в России. - [Plagiothecium berggrenianum (Plagiotheciaceae, Musci) in Russia] Бот. Журн. [Bot. Zhurn.] 81(2): 87-91. 
[VANA, J. \& M. S. IGNATOV] ВАНЯ, Й., М. С. ИГНАTOВ 1993. Печеночники Пинежского заповедника (Архангельская область) и общий очерк его бриофлоры [Hepatics of Pinega Reserve (Arkhangelsk Territory) and general outline of its bryoflora]. - Бюлл. Главн. бот. caда [Byull. Glavn. Bot. Sada] 167: 29-35.

VANA, J. \& M. S. IGNATOV 1995. Bryophytes of Altai Mountains. V. Preliminary list of the Altaian hepatics. - Arctoa 5: 1-13.

[VASILYEV, A. N.] ВАСИЛЬЕВ, А. Н. 1991. К бриофлоре черневой тайги Западного Саяна. - [On bryophyte flora of czernevaya taiga of Western Sayan] Флора $u$ растительность Сибири и Дальнего Востока (чтения памяти Л. М. Черепнина). Красноярск, ВБО и др. [Flora i Rastitelnost Sibiri i Dalnego Vostoka (Chteniya pamyati L. M. Czerepnina). Krasnoyarsk, Vsesoyuznoe Bot. Obshch. \& al.]: 19-21.

[VASILYEV, A. N.] ВАСИЛЬЕВ, А. Н. 1992. Конспект флоры мохообразных в заповедниках "Столбы" и СаяноШушенском. - [Bryophytes of Reserves "Stolby" and Sayano-Shushenskij] Красноярск, Изд-во Красноярск. унma [Krasnoyarsk, Izd. Krasnoyarks. Univ.], 112.

[VASILYEV, A. N.] ВАСИЛЬЕВ, А. Н. 1992. Географогенетический анализ бриофлоры Центральной части Южной Сибири. - [Geographo-genetic analysis of bryoflora of the central part of South Siberia] Ботаничекие исследования в Сибири, Красноярск, РБО и др. [Воtanicheskie issledovaniya v Sibiri, Krasnoyarsk, Ross. Bot. Obshch. \& al.]: 21-30.

[VASILYEV, А. N.] ВАСИЛЬЕВ, А. Н. 1995. Бриофлора центральной части Южной Сибири. - [Bryoflora of the central part of South Siberia] Aвтореф.... докт. биол. наук, Новосибирск, ЦСБС [Ph. D. Thesis, Novosibirsk, Centr. Sib. Bot. Sad], 32.

[VIRCHENKO, V. М.] ВIРЧЕНКО, В. М. 1993. Нова бріологічна література. - [New bryological literature] Укр. Бот. Журн. [Ukr. Bot. Zhurn.] 50(3): 150-153.

[VIRCHENKO, V. M.] ВІРЧЕНКО, В. М. 1995. Пропагулоносні Поліі (Bryaceae, Musci) у флорі Украіни. - [Propaguliferous Pohlias (Bryaceae, Musci) in flora of Ukraine] Укр. Бот. Журн. [Ukr. Bot. Zhurn.] 52(4): 495-501.

[VOLKOVA, L. А.] ВОЛКОВА, Л. А. 1993. Материалы к изучению бриофлоры Нижне-Свирского заповедника. - [Materials to study of moss flora of Nizhne-Svirski Reserve] Новости сист. низи. pacm. [Novosti Sist. Nizch. Rast.] 29: 138-144.

[VOLKOVA, L. A. \& A. I. MAKSIMOV] ВОЛКОВА, Л. А., А. И. МАКСИМОВ 1993. Список листостебельных мхов Карелии. - [Checklist of mosses of the Karelia] Растительный мир Карелии и проблемы его охраны (ред. Г. А. Елина, А. Д. Волков) Петрозаводск, Карельский научный чентр PAH. [In: Elina, G. A. \& A. D. Volkov (eds.) Rastitel'nyj mir Karelii i problemy ego okhrany. Petrozavodsk, Karel'skij nauchnyj tsentr Ross. Akad. Nauk]: 57-91.

[VOLKOVA, L. A. \& A. I. MAKSIMOV] ВОЛКОВА, Л. А., А. И. МАКСИМОВ 1995. Дополнение к флоре листостебельных мхов заповедника "Кивач"(Карелия). - [Addition to the moss flora of Kivacz Reserve (Karelia)] Hовости cист. низи. pacm. [Novosti Sist. Nizch. Rast.] 30: 97-98.
[VOLKOVA, L. A., A. L. ZHUKOVA, A. D. POTEMKIN \& N. D. NEMTSEVA] ВОЛКОВА, Л. А., А. Л. ЖУКОВА, А. Д. ПОТЕМКИН, Н. Д. НЕМЦЕВА 1994. Мохообразные Дарвинского государственного заповедника. - [Bryophytes of the Darvinsky State Reserve] Флора и растительность Тверской области (ред. М. В. Марков). Тверь, Тверской гос. ун-т [In: Markov, M. V. (ed.) Flora i rastitelnost' Tverskoi Oblasti. Tver', Tverskoj Gos. Univ.]: 13-24

[VYUNOVA, G. V.] ВЬЮНОВА, Г. В. 1992. В кн.: Очерки растительности особо охраняемых природных территорий Ленинградской области (ред. Боч, М. С. B. И. Василевич), СПб., БИН РАН [In: Botch, M. S. \& V. I. Vasilevich (eds.) Ocherki rastitel'nosti osobo ochranyaemykh prirodnykh territorij Leningradckoj oblasti, St.-Peterburg, Bot. Inst. Ross. Akad. Nauk]:

Списки мхов заказников - Lists of bryophytes of reserves: Котельский заказник [Kotel3kiy Reserve]: 115-116. Дудергофские высоты [Dudergoff Heights]: 132-133. Урочище Велькот [Vel'kot Natural Boundary]: 137. Урочище Донцо [Dontso Natural Boundary]: 143-144. Памятник природы "Репузи" [Regional Reserve "Repuzi”]: 148-149.

Памятник природы “Глядино” [Regional Reserve "Glyadino"]: 153-154.

Сяберский заказник [Sjaberskiy Reserve]: 182-183.

Шалово-Перечицкий заказника [Shalovo-Perechitskiy Reserve]: 193-194.

Череменецкий заказник [Cheremenetskiy Reserve]: 200-201. Памятник природы “Озеро Омчино” [Regional Reserve "Omchino Lake"]: 212-213.

[VYUNOVA, G. V. \& E. O. KUZMINA] ВЬЮНОВА, Г. В., Е. О. КУЗЬМИНА. 1991. Бриофлора республиканского заказника "Мшинское болото" (Ленинградская область). - [The bryoflora of reserve "Mshinskoe bog" (Leningrad Province)] Болота охраняемых территорий: проблемы охраны и мониторинга (ред. М. С. Боч) Л., ВБО и ЦЛГЗ [In: Botch, M. S. (ed.) Bolota okhranyaemykh territorij: problemy ochrany $i$ monitoringa. Leningrad, Vsesoyuz. Bot. Obshch. \& Centr. Lesnoi Gos. Zapovednik]: 43-46.

[ZHELEZNOVA, G. V.] ЖЕЛЕЗНОВА, Г. В. 1994. Флора листостебельных мхов Европейского Северо-Востока. - [Moss flora of European North-East] СПб., Наука [St.-Petersburg, Nauka], 148.

[ZHELEZNOVA, G. V. \& T. P. SHUBINA] ЖЕЛЕЗНОВА, Г. В., Т. П. ШУБИНА. 1993. Эколого-ценотическое распределение листостебельных мхов на Северном Урале. - [Ecologo-coenotic distribution of mosses in the North Ural] Споровые растения Крайнего Севера России (ред. Гецен, М. В. ), Сыктывкар, Инст. биол. КомиНЦ [In: Gezen, M. V. (ed.) Sporovye rasteniya Krajnego Severa Rossii, Syktyvkar, Inst. Biol. Komi Nauch. Centr]: 42-50.

[ZHELEZNOVA, G. V. \& T. P. SHUBINA] ЖЕЛЕЗНОВА, Г. В., Т. П. ШУБИНА. 1995. Лекарственные свойства мохообразных. - [The officinal properties of bryophytes] Лекарственные растения в природе и в культуре (ред. В. А. Мартыненко), Сыктывкар, Инст. биол. КомиНЦ [In: Martynenko, V. A. (ed.) Lekarstvennye Rasteniya v pripode $i v$ kulture, Syktyokar, Inst. Biol. Komi Nauch. Centr]: 32-40. 
[ZOLOTOV, V. I. \& N. N. РOPOVA] ЗОЛОТОВ, В. И., Н. Н. ПОПОВА 1995. Бриологическая характеристика некоторых болотных памятников природы Курской области. - [Bryological characteristics of some protected areas in Kursk Province] Проблемы сохранения разнообразия природы степных и лесостепных регионов (Мат. конф. 22-27 мая 1995, Курская обл., пос. Заповедный) (ред. Золотухин, Н. И.), М., КМК [In: Zolotukhin, N. I. (ed.) Problemy sokhraneniya raznoobraziya pripody stepnykh $i$ lesostepnykh regionov
(Mat. conf. 22-27 maya 1995, Kurskaya Obl., pos. Zapovednyj), Moskva, KMK]: 133-135.

[ZYKOV, I. V.] ЗЫКОВ, И. В. 1994. Аннотированный список мохообразных Тверской области. Печеночники: Jungermanniaceae-Frullaniaceae. - [Annotated list of bryophytes of Tver Province. Hepatics: Jungermanniaceae-Frullaniaceae] Флора и растительность Тверской области (ред. М. В. Марков). Тверь, Тверской гос. yн-m [In: Markov, M. V. (ed.) Flora i rastitelnost' Tverskoi Oblasti. Tver', Tverskoj Gos. Univ.]: 31-38. 